Jurnal Keperawatan Silampari

Volume 3, Nomor 2, Juni 2020

e-ISSN: 2581-1975

p-ISSN: 2597-7482

DOI: https://doi.org/10.31539/jks.v3i2.1036

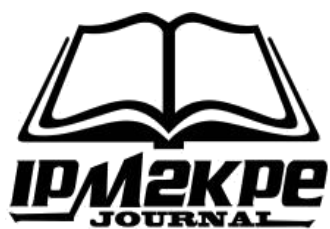

\title{
MODUL ASUHAN PERSALINAN KALA III DENGAN METODE PRECEPTORSHIP TERHADAP KETERAMPILAN MAHASISWA DIII KEBIDANAN
}

\author{
Yatri Hilinti ${ }^{1}$, Prastawa Budi ${ }^{2}$, Mardiana Ahmad ${ }^{3}$ \\ Universitas Hasanuddin Makassar ${ }^{1,2,3}$ \\ yatrihilinti1990@gmail.com ${ }^{1}$
}

\begin{abstract}
ABSTRAK
Penelitian ini bertujuan untuk menganalisis pengaruh modul asuhan persalinan kala III dengan metode preceptorship terhadap keterampilan mahasiswa DIII Kebidanan. Desain penelitian yang digunakan dalam penelitian ini adalah quasy eksperiment. Hasil penelitian menunjukkan bahwa modul dan metode preceptorship lebih baik dalam meningkatkan keterampilan mahasiswa melakukan asuhan persalinan kala III. Simpulan, terjadi peningkatan keterampilan mahasiswa pada seluruh kelompok yaitu kelompok demonstrasi, modul dan demonstrasi serta modul dan preceptorship, peningkatan keterampilan asuhan persalinan kala III paling tinggi didapatkan oleh kelompok yang diberikan modul asuhan persalinan kala III dan metode preceptorship dibandingkan kelompok demonstrasi serta modul dan kelompok demonstrasi tanpa intervensi modul asuhan persalinan kala III
\end{abstract}

Kata Kunci : Kala III, Keterampilan, Modul, Persalinan, Preceptorship

\section{ABSTRACT}

This study aims to analyze the effect of the third stage of childbirth care modules with the preceptorship method on the skills of midwifery DIII students. The research design used in this study was quasy experiment. The results showed that the modules and preceptorship methods were better in improving the skills of students doing third stage of childbirth care. Conclusion, there was an increase in student skills in all groups namely the demonstration group, modules and demonstrations as well as the modules and preceptorship, the highest increase in the skills of third stage of childbirth care was obtained by the group given the third stage of childbirth care modules and the preceptorship method compared to the demonstration group and the modules and demonstration groups without the intervention of the third stage of childbirth care modules

Keywords: Stage III, Skills, Modules, Delivery, Preceptorship

\section{PENDAHULUAN}

Perdarahan postpartum menyumbang 127.000 kematian setiap tahun di seluruh dunia dan insidensinya meningkat di negara maju. Ini adalah penyebab utama kematian ibu secara global. Manajemen aktif Kala III persalinan direkomendasikan sebagai strategi preventif mencegah perdarahan. Manajemen aktif terdiri dari langkah-langkah untuk mengurangi lama kala III persalinan dan mengurangi kehilangan darah. 
Uterotonik dan penjepitan tali pusat segera adalah teknik yang sangat disarankan. Rekomendasi saat ini menyatakan bahwa pemotongan tali pusat harus ditunda dan sangat bermanfaat bagi neonatus (Vasconcelos et al., 2018). Mengingat pentingnya asuhan persalinan kala III yang tepat, maka mahasiswa diharuskan terampil dalam melakukan asuhan persalinan kala III mulai dari tingkat diploma.

Pembelajaran asuhan kebidanan bersifat teoritis, dosen pengajar seringkali tidak memiliki pengalaman klinis, cara belajar mahasiswa cenderung menghafal sehingga tidak menjawab masalah kognitif. Sikap tidak dibangun berdasarkan kebutuhan setiap kasus, sehingga ranah afektif pun masih kurang. Keterampilan (psikomotor) dibangun berdasarkan konsep yang statis dan tidak berdasarkan kebutuhan klien. Sangat dibutuhkan media dan metode pembelajaran yang dapat meningkatkan kemampuan mahasiswa pada aspek kognitif, afektif dan psikomotor sebagai upaya meningkatkan kemampuan mahasiswa memberikan asuhan persalinan.

Media pembelajaran yang dapat digunakan oleh mahasiswa dalam mempelajari asuhan persalinan kala III yaitu modul. Modul akan memungkinkan peserta didik untuk melakukan perubahan dalam praktik sehari-hari atau dalam memberikan pelayanan kesehatan. Hasil penelitian di London menunjukkan 33,3\% siswa menganggap modul dapat meningkatkan kemampuan pra-pelatihan pengelolaan wanita menjelang kelahiran optimal. Penilaian keseluruhan pelatihan dianggap baik oleh $23,1 \%$ peserta dan sangat baik oleh 76,9\% peserta (Coates et al., 2018).

Modul mendorong mahasiswa untuk melihat dan mengingat kembali apa yang telah disampaikan dalam kegiatan belajar di kelas. Modul dapat membantu dalam pencapaian tujuan pembelajaran (Ruwihapsari \& Maryana, 2018). Beberapa keuntungan dalam penggunaan modul tersebut menjadi suatu gagasan peneliti membuat modul yang dapat digunakan dalam pendidikan kebidanan khususnya diploma III Kebidanan. Kompetensi yang wajib dimiliki dan dikuasai bidan salah satunya adalah pertolongan persalinan yang didalamnya memuat keterampilan asuhan kala III (Setyorini, 2017). Kala III merupakan kala pelepasan plasenta (Rahmadhayanti, Kamtini, 2018). Maka, peneliti termotivasi untuk merancang bahan pembelajaran berupa modul asuhan persalinan kala III.

Pencapaian kompetensi mahasiswa dapat ditingkatkan melalui kegiatan latihan di laboratorium klinik atau latihan langsung di lahan. Pada proses ini dosen sangat bertanggung jawab untuk memudahkan interaksi mahasiswa pada lingkungan belajarnya dan menciptakan lingkungan pendidikan yang memungkinkan siswa memperoleh keterampilan dan kompetensi (Utami, 2018). Salah satu upaya yang dapat menjadi pilihan dosen yaitu dengan memilih metode pembelajaran preceptorship. Precepetorship adalah pembelajaran dimana pengetahuan dan keterampilan dihasilkan melalui partisipasi dalam praktik klinik. Dengan cara ini, mahasiswa dapat mengembangkan penilaian klinis dan independensi dalam pelayanan kepada pasien (Nielsen et al., 2017). Pembelajaran dengan metode preceptorship juga telah diusulkan sebagai strategi pedagogis yang dapat mempengaruhi perkembangan moral mahasiswa (Vihos et al., 2019).

Preceptorship dalam penelitian klinis dan translasional dirancang untuk memberikan kesempatan bagi mahasiswa melakukan praktik klinik atau translasi praktik melalui pengalaman pembelajaran saat magang dengan preceptor (Stefely et al., 2019). Preceptor memahami bahwa tugas penting mahasiswa adalah untuk menemukan motivasi, kepercayaan diri dan tujuan pembelajaran dengan melakukan praktik klinis dan menciptakan mahasiswa menjadi dirinya sendiri. Dalam prosesnya diciptakan 
lingkungan belajar yang paling nyaman dan mahasiswa bebas mengajukan pertanyaan dan merefleksikannya secara langsung. Preceptor juga menekankan perlunya menemukan kebutuhan belajar mahasiswa, memberi batasan tugas, serta memberikan umpan balik yang konstruktif pada mahasiswa (Nygren, Carlson, 2017).

Penelitian di Iran pada mahasiswa keperawatan dan kebidanan, pembelajaran dengan metode preceptorship mampu meningkatkan nilai rata-rata standar deviasi (SD) efikasi diri dan hasil belajar siswa yaitu 30,69 $(5,88)$ dan 4,10 $(0,82)$ (Fazelniya et al., 2018). Studi kualitatif tentang metode preceptorship pada mahasiswa keperawatan mendapati 3 temuan yaitu 1) Bersatu: preceptee dan preceptor hadir secara fisik di ruang yang sama mengoptimalkan situasi belajar dengan fokus pada kompleksitas, penggunaan indra dan keselamatan pasien, 2) Melakukan pekerjaan bersama-sama: preceptee dan preceptor melakukan pelayanan keperawatan bersama untuk mendapatkan keterampilan yang berfokus pada kemandirian, keterampilan praktis dan komunikasi, 3) Bergaul bersama: preceptee dan preceptor berfokus pada pasien, hubungan, kenyamanan, dan menjaga keseimbangan antara hubungan profesional dan pribadi (Nielsen et al., 2017).

Survey awal yang dilakukan peneliti pada beberapa institusi kesehatan di Makassar, didapatkan tingkat kelulusan pada ujian keterampilan asuhan persalinan masih rendah $(36,6 \%)$ termasuk tindakan asuhan persalinan kala III. Akademi Kebidanan (AKBID) Pelamonia merupakan salah satu institusi yang seluruh dosen mengajar asuhan kebidanan telah mengikuti pelatihan preceptorship, namun kegiatan pembelajaran praktikum masih menggunakan metode demonstrasi dan tidak menggunakan modul sebagai media pembelajaran. Jumlah mahasiswa yang mendapatkan matakuliah asuhan kebidanan persalinan saat ini adalah 161 orang. Data pada bagian evaluasi AKBID Pelamonia menunjukkan jumlah mahasiswa yang dinyatakan terampil pada ujian OSCE Asuhan persalinan tahun 2018 hanya 42,6\%.

Penelitian ini menyatukan metode pembelajaran preceptorship berbantu modul asuhan persalinan kala III yang ditulis sendiri oleh peneliti dan telah melalui uji validasi oleh ahli materi dan ahli media serta telah melalui uji coba pada mahasiswa.

\section{METODE PENELITIAN}

\section{Desain penelitian}

Penelitian ini menggunakan desain quasy eksperiment (pretest-posttest control group design). Penelitian ini terdiri dari 3 (tiga) kelompok yaitu kelompok demonstrasi, kelompok modul \& demonstrasi, dan kelompok modul \& preceptorship.

\section{Subjek}

Populasi dalam penelitian ini adalah seluruh mahasiswa Akademi Kebidanan Pelamonia Kesdam VII/ Wirabuana Makassar yang mendapatkan mata kuliah asuhan kebidanan persalinan tahun ajaran 2019/2020 yang berjumlah 141 orang. Pengambilan Sampel dalam penelitian ini yaitu dengan teknik total sampling (141 orang).

\section{Data Collection Prosedur}

Sebanyak 141 orang mahasiswa diberikan lembar responden dan seluruhnya setuju untuk dilakukan intervensi media dan metode pembelajaran dalam matakuliah asuhan persalinan. Responden dibagi kedalam 3 kelompok dengan intervensi yang berbeda yaitu kelompok demonstrasi, kelompok modul \& demonstrasi, dan kelompok modul \& preceptorship. 


\section{Intervention Group}

Intervensi dilakukan dengan pembelajaran metode demonstrasi oleh dosen tanpa pelatihan preceptor dan metode preceptorship oleh dosen yang telah memiliki sertifikat preceptor, jenjang pendidikan minimal S2 kebidanan dan telah bekerja menolong persalinan minimal 5 tahun. Kedua kelompok tersebut masing-masing diberikan modul asuhan persalinan yang dibuat oleh peneliti sendiri serta telah divalidasi. Kelompok kontrol adalah kelompok dengan metode pembelajaran demonstrasi saja tanpa diberikan modul asuhan persalinan kala III. Pembelajaran di laboratorium dilakukan sebanyak 3 kali pertemuan selama 2x50 menit/pertemuan dengan selang waktu pertemuan \pm 7 hari.

\section{Ethical Consideration}

Penelitian ini telah mendapatkan persetujuan etik dari Komisi Etik Fakultas Kedokteran Universitas Hasanuddin Makassar nomor: 1046/UN4.6.4.5.31/PP36/2019. Penelitian dilakukan dengan persetujuan dari mahasiswa, dosen dan preceptor. Peneliti menjamin kerahasiaan responden dan responden diberikan hak untuk mengundurkan diri sebagai responden pada saat penelitian atau kapanpun tanpa implikasi untuk perlakuan selanjutnya.

\section{Statistik Analysis}

Peneliti melakukan pengolahan data secara komputerisasi dengan menggunakan program Statistical Product and Service Solution (SPSS) dengan tipe IBM SPSS Statistics 25. Analisis data dengan menggunakan analisis univariat untuk mengetahui distribusi frekuensi, analisis bivariat untuk mengetahui pengaruh intervensi terhadap kelompok dan analisis multivariat untuk mengetahui seberapa besar pengaruh antara variabel independen dan dependen. Analisis dalam penelitian ini menggunakan uji statistik yaitu uji chy square dan Mann withney.

\section{HASIL PENELITIAN Karakteristik responden}

Tabel. 1

Karakteristik Responden Kelompok Intervensi dan Kontrol

\begin{tabular}{|c|c|c|c|c|c|c|c|}
\hline \multirow{3}{*}{ Variabel } & \multicolumn{6}{|c|}{ Kelompok } & \multirow{3}{*}{ P-Value } \\
\hline & \multicolumn{2}{|c|}{ Demonstrasi } & \multicolumn{2}{|c|}{$\begin{array}{c}\text { Modul \& } \\
\text { Demonstrasi }\end{array}$} & \multicolumn{2}{|c|}{$\begin{array}{c}\text { Modul \& } \\
\text { Preceptorship }\end{array}$} & \\
\hline & $\mathrm{n}$ & $\%$ & $\mathrm{~N}$ & $\%$ & $\mathrm{~N}$ & $\%$ & \\
\hline \multicolumn{8}{|l|}{ Umur } \\
\hline$<23$ tahun & 46 & 95,8 & 46 & 100 & 47 & 100 & \multirow{3}{*}{0,085} \\
\hline$\geq 23$ tahun & 2 & 4,2 & 0 & 0 & 0 & 0 & \\
\hline Total & 48 & 100 & 46 & 100 & 47 & 100 & \\
\hline \multicolumn{8}{|l|}{ IPK } \\
\hline Memuaskan & 1 & 33 & 0 & 0 & 1 & 0,7 & \multirow{4}{*}{0,259} \\
\hline Sangat memuaskan & 33 & 68,8 & 28 & 60,9 & 38 & 80,9 & \\
\hline Dengan Pujian & 14 & 29,2 & 18 & 39,1 & 9 & 19,1 & \\
\hline Total & 48 & 100 & 46 & 100 & 47 & 100 & \\
\hline
\end{tabular}




\begin{tabular}{cccccccc}
\hline \multicolumn{2}{l}{ Tingkat Ekonomi Keluarga } & & & & & & \\
Rendah & 8 & 16,7 & 12 & 26,1 & 10 & 21,3 & \\
Sedang & 22 & 45,8 & 19 & 41,3 & 22 & 46,8 & 0,279 \\
Tinggi & 18 & 37,5 & 15 & 32,6 & 15 & 31,9 & \\
Total & 48 & 100 & 46 & 100 & 47 & 100 & \\
\hline
\end{tabular}

Tabel 1 menunjukkan tidak ada perbedaan yang signifikan antara masing-masing kelompok dilihat dari umur, IPK, dan tingkat ekonomi keluarga. Hampir seluruh responden dari kelompok kontrol $(94,3 \%)$ berusia dibawah 23 tahun. Sedangkan pada kelompok intervensi modul \&demonstrasi serta modul \& preceptorship didapatkan seluruh responden $(100 \%)$ berusia $<23$ tahun. Distribusi IPK pada kelompok intervensi modul \& demonstrasi sebagian besar $(57,4 \%)$ sangat memuaskan dan hampir sebagian $(42,6)$ dengan pujian, sementara pada kelompok modul dan preceptorship lebih dari sebagian kelompok $(79,6)$ mendapatkan IPK sangat memuaskan dan sebagian kecil $(20,4 \%)$ memiliki IPK dengan predikat dengan pujian, sementara pada kelompok kontrol lebih dari sebagian (66\%) mendapatkan predikat sangat memuaskan dan kurang dari sebagian $(37,7 \%)$ dengan predikat dengan pujian.

Distribusi tingkat ekonomi keluarga pada kelompok intervensi modul \& demonstrasi hampir sebagian $(42,6)$ tergolong ekonomi sedang dan kurang dari sebagian kelompok $(37,7)$ dengan tingkat ekonomi tinggi, sedangkan pada kelompok intervensi modul \& preceptorship hampir sebagian kelompok $(48,1 \%)$ dengan tingkat ekonomi sedang dan sebagian kecil $(29,6 \%)$ dengan tingkat ekonomi tinggi.

Tabel. 2

Perbedaan Keterampilan Asuhan Bayi Baru Lahir Sebelum dan Sesudah Intervensi pada Kelompok Intervensi dan Kontrol

\begin{tabular}{|c|c|c|c|c|c|}
\hline \multicolumn{6}{|c|}{ Keterampilan Asuhan Bayi Baru Lahir Kala III Persalinan } \\
\hline \multirow{2}{*}{ Kelompok } & \multicolumn{2}{|c|}{ Terampil } & \multicolumn{2}{|c|}{$\begin{array}{c}\text { Tidak } \\
\text { Terampil }\end{array}$} & \multirow{2}{*}{ P-value } \\
\hline & $\mathrm{N}$ & $\%$ & $\mathrm{n}$ & $\%$ & \\
\hline \multicolumn{6}{|l|}{ Pre test } \\
\hline Demonstrasi (Kontrol) & 7 & 14,6 & 41 & 85,4 & \multirow{3}{*}{$0,071^{\mathrm{a}}$} \\
\hline Modul dan Demonstrasi & 3 & 6,5 & 43 & 93,5 & \\
\hline Modul dan Preceptorship & 2 & 4,3 & 45 & 95,7 & \\
\hline \multicolumn{6}{|l|}{ Post test } \\
\hline Demonstrasi (Kontrol) & 32 & 66,7 & 16 & 33,3 & \multirow{3}{*}{$0,000^{\mathrm{a}}$} \\
\hline Modul dan Demonstrasi & 38 & 82,6 & 7 & 15,2 & \\
\hline Modul dan Preceptorship & 45 & 95,7 & 2 & 4,3 & \\
\hline
\end{tabular}

${ }^{a}$ Mann-Whitney

Tabel 2 pada hasil pre-test menunjukkan tidak ada perbedaan yang signifikan pada masing-masing kelompok dalam keterampilan tindakan asuhan bayi baru lahir. Sebaliknya pada hasil post-test terdapat perbedaan yang signifikan pada masing-masing kelompok dalam melakukan asuhan bayi baru lahir saat kala III persalinan. 
Tabel 2 menunjukkan bahwa sebelum dilakukan intervensi kelompok demonstrasi hanya sebagian kecil $(14,6 \%)$ mahasiswa yang terampil dan setelah dilakukan pembelajaran dengan metode demonstrasi menjadi lebih dari sebagian $(66,7 \%)$ terampil melakukan asuhan bayi baru lahir kala III persalinan. Pada kelompok modul dan demonstrasi, hanya 6,5\% mahasiswa yang terampil melakukan tindakan asuhan persalinan dan meningkat lebih dari sebagian responden $(82,6 \%)$ terampil melakukan tindakan asuhan persalinan bayi baru lahir. Sedangkan kelompok lainnya, sebelum dilakukan intervensi hanya 4,3\% terampil dan meningkat menjadi hamper seluruhnya $(95,7 \%)$ terampil melakukan tindakan asuhan bayi baru lahir setelah dilakukan intervensi modul dengan metode preceptorship.

Tabel. 3

Perbedaan Keterampilan Manajemen Aktif Kala III Sebelum dan Sesudah Intervensi pada Kelompok Intervensi dan Kontrol

\begin{tabular}{|c|c|c|c|c|c|}
\hline \multicolumn{6}{|c|}{ Keterampilan Manajemen Aktif Kala III } \\
\hline \multirow{2}{*}{ Kelompok } & \multicolumn{2}{|c|}{ Terampil } & \multicolumn{2}{|c|}{$\begin{array}{c}\text { Tidak } \\
\text { Terampil }\end{array}$} & \multirow{2}{*}{ P-value } \\
\hline & $\mathrm{N}$ & $\%$ & $\mathrm{~N}$ & $\%$ & \\
\hline \multicolumn{6}{|l|}{ Pre test } \\
\hline Demonstrasi (Kontrol) & 6 & 12,5 & 42 & 87,5 & \multirow{3}{*}{$0,350^{\mathrm{a}}$} \\
\hline Modul dan Demonstrasi & 4 & 8,7 & 42 & 91,3 & \\
\hline Modul dan Preceptorship & 9 & 19,1 & 38 & 80,9 & \\
\hline \multicolumn{6}{|l|}{ Post test } \\
\hline Demonstrasi (Kontrol) & 35 & 72,9 & 13 & 27,1 & \multirow{3}{*}{$0,010^{\mathrm{a}}$} \\
\hline Modul dan Demonstrasi & 36 & 78,3 & 10 & 21,7 & \\
\hline Modul dan Preceptorship & 44 & 93,6 & 3 & 6,4 & \\
\hline
\end{tabular}

Tabel 3 menunjukkan sebelum dilakukan intervensi, tidak ada perbedaan yang signifikan pada masing-masing kelompok dalam keterampilan tindakan Manajemen Aktif Kala III. Sebaliknya setelah dilakukan intervensi terdapat perbedaan yang signifikan pada masing-masing kelompok dalam melakukan tindakan manajemen aktif kala III.

Tabel 3 menunjukkan responden yang terampil hanya sebagian kecil $(12,5 \%)$ sebelum dilakukan pembelajaran dengan metode demonstrasi meningkat menjadi lebih dari sebagian $(72,9 \%)$ setelah dilakukan pembelajaran dengan metode preceptorship. Pada kelompok modul dan demonstrasi, sebelum dilakukan intervensi hanya sebagian kecil $(8,7 \%)$ mahasiswa yang terampil dan meningkat menjadi lebih dari sebagian $(78,3 \%)$ mahasiswa terampil melakukan tindakan manajemen aktif kala III. Sedangkan pada kelompok modul dan prceptorship didapatkan hanya sebagian kecil $(19,1)$ mahasiswa yang terampil dan meningkat menjadi hampir seluruh $(93,6 \%)$ mahasiswa terampil setelah diberikan media pembelajaran modul asuhan persalinan kala III dan metode pembelajaran preceptorship. 
Tabel. 4

Perbedaan Keterampilan Pemantauan Perdarahan Sebelum dan Sesuadah Intervensi pada Kelompok Intervensi dan Kontrol

\begin{tabular}{lccccc}
\hline \multicolumn{7}{c}{ Tindakan Pemantauan Perdarahan } \\
\hline \multirow{2}{*}{ Kelompok } & \multicolumn{2}{c}{ Terampil } & \multicolumn{2}{c}{ Tidak Terampil } & \multirow{2}{*}{ P-value } \\
\cline { 2 - 5 } & $\mathrm{N}$ & $\%$ & $\mathrm{~N}$ & $\%$ & \\
\hline Pre test & 8 & 16,7 & 40 & 83,3 & \multirow{2}{*}{$0,293^{\mathrm{a}}$} \\
Demonstrasi (Kontrol) & 10 & 21,7 & 36 & 78,3 & \\
Modul dan Demonstrasi & 12 & 25,5 & 35 & 74,5 & \\
Modul dan Preceptorship & & & & & \\
\hline Post test & 29 & 60,4 & 19 & 39,6 & \\
Demonstrasi (Kontrol) & 32 & 69,6 & 14 & 30,4 & $0,000^{\mathrm{a}}$ \\
Modul dan Demonstrasi & 45 & 95,7 & 2 & 4,3 & \\
Modul dan Preceptorship & 45 & & & &
\end{tabular}

${ }^{a}$ Mann Whitney

Tabel 4 menunjukkan sebelum dilakukan intervensi, tidak ada perbedaan yang signifikan pada masing-masing kelompok dalam keterampilan tindakan pematauan perdarahan. Sebaliknya setelah dilakukan intervensi terdapat perbedaan yang signifikan pada masing-masing kelompok dalam melakukan tindakan pematauan perdarahan.

Tabel 4 menunjukkan keterampilan pemantauan perdarahan pada kelompok kontrol sebelum dilakukan pembelajaran dengan metode demonstrasi sebagian kecil $(16,7 \%)$ terampil dan meningkat menjadi lebih dari sebagian $(60,4 \%)$ setelah dilakukan metode demonstrasi. Pada kelompok modul dan demonstrasi sebelum dilakukan intervensi hampir sebagian $(21,7 \%)$ menjadi lebih dari sebagian $(69,6 \%)$ terampil melakukan tindakan pemantauan perdarahan. Sedangkan pada kelompok lainya, sebelum dilakukan intervensi sebagian kecil $(25,5 \%)$ terampil menjadi hampir seluruh responden $(95,7 \%)$ terampil melakukan pemantauan perdarahan kala III persalinan setelah dilakukan pembelajaran dengan modul asuhan persalinan kala III dengan metode pembelajaran preceptorship.

\section{PEMBAHASAN}

\section{Karakteristik responden}

Hasil uji statistik menunjukkan tidak ada perbedaan yang bermakna pada karakteristik responden kelompok demonstrasi, modul dan demonstrasi serta modul dan preceptorship baik umur, IPK, Tingkat ekonomi keluarga dan kepercayaan diri. Umur mahasiswa setiap kelompok hampir sama yaitu $<23$ tahun karena untuk menjadi mahasiswa kebidanan umur ditentukan <25 tahun bagi mahasiswa reguler. Masingmasing kelompok menunjukkan IPK yang baik, karena nilai mata kuliah asuhan kehamilan menjadi persyaratan mahasiswa tersebut untuk mengikuti mata kuliah asuhan persalinan. Untuk menjadi mahasiswa kebidanan yang menjadi syarat utama kelulusan penerimaan mahasiswa bidan adalah nilai tes tertulis dan kesehatan, sedangkan pembiayaan sewaktu kuliah dapat dibantu dengan beasiswa ataupun anggota keluarga yang lain. Setiap kelompok juga terlihat memiliki kepercayaan diri dalam melakukan tindakan asuhan persalinan kala III. 


\section{Perubahan Keterampilan Mahasiswa}

Keterampilan mahasiswa dimaksudkan dalam penelitian ini adalah kemampuan mahasiswa dalam melakukan asuhan persalinan kala III. Dalam penelitian ini metode pembelajaran yang digunakan untuk menilai keterampilan asuhan persalinan kala III pada kelompok intervensi dan kelompok kontrol adalah metode demonstrasi dan preceptorship. Sebuah penelitian menunjukkan ada pengaruh yang signifikan antara kemampuan ibu menyusui sebelum dan sesudah dilakukan penyuluhan dengan metode demonstrasi (Astuti, Surasmis, 2016).

Keterampilan mahasiswa sebelum intervensi dalam penelitian ini memberikan asuhan persalinan kala III menunjukan tidak ada perbedaan antara ketiga kelompok. Hal ini dikarenakan ketiga kelompok tersebut belum mendapatkan pembelajaran praktik di laboratorium sebelumnya. Setelah dilakukan intervensi dengan metode demonstrasi, memberikan bahan ajar berupa modul dan metode preceptorship, terdapat peningkatan keterampilan asuhan persalinan kala III pada kelompok intervensi dibandingkan kelompok kontrol yang hanya mendapatkan metode demonstrasi saja. Dengan diberikannya modul, mahasiswa dapat mempelajari materi dan praktikum secara mandiri dan berulang (Rahmadhayanti, Kamtini, 2018). Mahasiswa telah siap sebelum pembelajaran di laboratorium, dan mahasiswa dapat kembali mengulang pembelajaran dengan mudah melalui modul asuhan persalinan kala III yang diberikan sehingga keterampilan mahasiswa dapat ditingkatkan.

Hasil penelitian ini menunjukkan adanya peningkatan pada keterampilan mahasiswa dengan adanya media pembelajaran modul asuhan persalinan kala III. Penelitian ini sejalan dengan penelitian Coates tahun 2018 yang menunjukkan bahwa modul meningkatkan keterampilan, pengetahuan, dan kepercayaan diri peserta yang dilaporkan dalam mempraktikkan kelahiran optimal (Coates et al., 2018).

\section{Pengaruh Modul dalam Perubahan Keterampilan Mahasiswa}

Hasil penelitian membuktikan pembelajaran menggunakan modul efektif untuk meningkatkan skor keterampilan. Penelitian lainnya yang dilakukan di Irlandia pada tahun 2016 menunjukkan bahwa modul kesehatan mental perinatal efektif untuk meningkatkan pengetahuan, keterampilan, dan sikap mahasiswa sarjana kebidanan dalam melakukan pelayanan kesehatan pada wanita dengan masalah kesehatan mental (Davies et al., 2016; Higgins et al., 2016).

Kompetensi adalah karakteristik yang mendasari seseorang berkaitan dengan efektivitas kinerja dan tindakan yang cerdas, penuh tanggung jawab sebagai syarat agar mampu serta memiliki hubungan sebab akibat dengan kriteria yang dijadikan sebagai acuan atau kemampuan untuk melaksanakan tugas yang dilandasi oleh keterampilan dan pegetahuan yang didukung juga oleh sikap kerja seorang bidan dalam melaksanakan praktek kebidanan pada setiap pelayanan kesehatan yang aman dan sesuai standar (Nurmala, 2018). Sehingga untuk memberikan pelayanan kebidanan sesuai standar maka mahasiswa harus kompeten, meningkatkan kompetensi mahasiswa salah satunya adalah dengan memberikan metode pembelajaran dan media pembelajaran sesuai kebutuhan mahasiswa sehingga mahasiswa tersebut lebih terampil dalam setiap praktik asuhan kebidanan.

Pada penelitian ini dibuat suatu media pembelajaran yang mengintegrasikan kebutuhan ibu bersalin dengan nilai-nilai dari substansi bidang keilmuan lainnya serta mengintegrasikannya dalam tata nilai yang dikembangkan yaitu soft skill (sikap sabar, empati dan teliti) yang bertujuan agar keterampilan mahasiswa melakukan asuhan bayi 
baru lahir meningkat. Media tersebut adalah modul asuhan persalinan kala III. Peningkatan keterampilan menunjukkan hasil bahwa keterampilan pada kelompok modul dan demonstrasi dapat meningkat sebesar $76,1 \%$ sedangkan pada kelompok demonstrasi tanpa diberikan modul peningkatan keterampilan sebesar 52,1\%.

Hasil keterampilan mahasiswa adalah baik. Dari kelompok intervensi modul asuhan persalinan kala III yang paling banyak salah atau tidak sempurna dalam melakukan tindakan asuhan bayi baru lahir terbanyak adalah pada langkah ke-8 yaitu meletakkan bayi tengkurap di dada ibu untuk kontak kulit ibu-bayi, posisikan bayi dengan bahu yang lurus dan kepala berada diantara kedua payudara ibu dan lebih rendah dari putting susu ibu. Biarkan selama 1 jam dan bayi dapat mencari putting susu ibu. Pastikan bayi tetap hangat dengan memasangkan topi dan menyelimutinya.Hal ini dikarenakan mahasiswa tidak memperhatikan posisi bayi dan tidak memberikan topi.Maka dari itu diperlukan upaya dari mahasiswa untuk kembali mengulang prosedur tindakan di laboratorium dibantu dengan bahan ajar berupa modul.

Hasil keterampilan manajemen aktif kala III dalam penelitian ini menunjukkan adanya peningkatkan keterampilan pada kelompok intervensi modul asuhan persalinan sebesar 69,6\% dibandingkan kelompok yang tidak mendapatkan modul mengalami peningkatan keterampilan sebesar $60,4 \%$. Point yang paling banyak salah yaitu langkah ke-6 yaitu Melakukan masase uterus segera setelah plasenta dan selaput ketuban lahir, penolong meletakkan telapak tangan di fundus dan lakukan masase dengan gerakan melingkar dengan lembut hingga uterus berkontrasi (fundus teraba keras). Hal ini dikarenakan banyak mahasiswa yang lupa melakukan tindakan masase uterus segera.

Hasil penelitian tersebut sejalan dengan penelitian Setyorini (2017) yang menunjukkan bahwa sebagian besar mahasiswa mempunyai keterampilan yang cukup tentang manajemen aktif kala III, yaitu ada 117 mahasiswa $(61,9 \%)$ dan ada $11(5,8 \%)$ mahasiswa yang mempunyai keterampilan kurang tentang manajemen aktif kala III. Hal tersebut dipengaruhi oleh motivasi atau motif belajar, faktor ekternal, perhatian orang tua, lingkungan belajar dan metode pembelajaran yang sesuai dengan kebutuhan mahasiswa.

Keterampilan pemantauan perdarahan pada kala III hanya terdiri dari 2 lagkah keterampilan. Mahasiswa juga mengalami peningkatan keterampilan sebesar 47,9\% pada kelompok demonstrasi dan modul, sedangkan pada kelompok demonstrasi saja mengalami peningkatan keterampilan sebesar $43,7 \%$. Point keterampilan yang paling banyak salah yaitu pada langkah ke-1 yaitu mengevaluasi kemungkinan laserasi pada vagina dan perineum.melakukanpenjahitan bila terjadi laserasi yang luas dan menimbulkan perdarahan. Hal ini kurang tepat dalam melakukan pemeriksaan laserasi dan bahkan tidak dilakukan pemeriksaan laserasi. Sedangkan Motivasi tidak berpengaruh pada kompetensi mahasiswa, hal ini disebabkan oleh beberapa faktor, seperti: faktor mahasiswa, lingkungan keluarga dan lingkungan pembelajaran. Kompetensi sangat berperan terhadap kepuasan pasien pada asuhan yang diberikan mahasiswa pada praktik klinik kebidanan. Kompetensi yang paling berperan terhadap kepuasan pasien terletak pada aspek sikap.

Keterampilan pemantauan perdarahan merupakan suatu sikap yang akan mempengaruhi kepuasan pasien dalam menerima pelayanan yang mahasiswa lakukan di tempat pelayanan kesehatan. Dari data tersebut, dapat diketahui bahwa adanya pembelajaran dengan modul sangat membantu dalam meningkatkan keterampilan mahasiswa melakukan asuhan bayi baru lahir, manajemen aktif kala III dan pemantauan perdarahan dalam rangkaian tindakan pertolongan persalinan normal pada kala III. 
Kebutuhan manusia tidak dapat dipisahkan dari sikap disiplin yang merupakan suatu holistik yang terdiri dari biologi, fisik, emosional, intelektual, sosial dan spiritual. Mahasiswa harus dilatih untuk dapat mengkombinasikan pengetahuan, keterampilan dan sikap sehingga dapat memenuhi kebutuhan masyarakat secara utuh.pembelajaran terintegrasi dapat memotivasi mahasiswa dikarenakan sifatnya yang relevan dan mengikuti prinsip-kontruktivisme. Integrasi merupakan prinsip penting pada pelaksanaan pendidikan terpadu, karateristiknya meliputi holistik, bermakna, otentik dan aktif (Nurmala, 2018).

\section{Pengaruh Modul Asuhan Persalinan Kala III dan Metode Preceptorship pada Keterampilan Mahasiswa}

Hasil penelitian menunjukkan bahwa keterampilan mahasiswa kebidanan melakukan tindakan persalinan kala III paling tinggi peningkatannya pada penggunaan modul bersamaan dengan metode preceptorship. Keterampilan asuhan bayi baru lahir meningkat sebesar 79,6\% pada kelompok modul dan preceptorship, 72,2\% pada kelompok modul dan demonstrasi serta $60,3 \%$ pada kelompok demonstrasi saja. Hal yang sama ditunjukkan pada tabel 3, keterampilan mahasiswa dalam melakukan manajemen aktif kala III meningkat paling tinggi yaitu 66,6\% dibandingkan kelompok modul dan demonstrasi $(62,6 \%)$ serta demonstrasi saja (60\%). Pada keterampilan pemantauan perdarahan keterampilan mahasiswa meningkat sebesar $48,1 \%$. Persentase peningkatan tersebut lebih tinggi daripada kelompok modul dan demonstrasi $(33,5 \%)$ serta kelompok demonstrasi saja $(26,4 \%)$.

Hasil penelitian tersebut sejalan dengan penelitian yang dilakukan di Bandung yaitu terdapat perbedaan bermakna keterampilan pemeriksaan kehamilan antara metode preceptorship dengan konvensional (Susanti et al., 2016). Penelitian lainnya menunjukkan hasil pembelajaran preceptorship mendapatkan nilai rerata pre-test sebesar 30,45 dan nilai post-test sebesar 45,5 dengan rerata peningkatan nilai antara pre dan post-test sebesar 10,9. Kegiatan ini dapat meningkatkan pemahaman pembimbing klinik tentang metode perceptorship (Lestari et al., 2019).

Pada kelompok modul dan preceptorship mahasiswa melakukan pendekatan pembelajaran dimana peserta didik secara individual ditugaskan untuk mempromosikan sosialisasi bagi mahasiswa dalam profesinya dan memperoleh nilai-nilai serta identitas profesional. Mahasiswa akan lebih terampil jika metode pembelajaran yang baik digabungkan dengan media pembelajaran yang tepat (Vihos et al., 2019). Metode pembelajaran preceptorship dirancang denga tujuan memberikan kesempatan kepada mahasiswa melakukakan praktik klinis melalui berbagai pengalaman pembelajaran praktik dibantu oleh preceptor (Stefely et al., 2019).

Preceptorship adalah metode pembelajaran untuk meningkatkan pelayanan kesehatan dengan melakukan pengembangan keterampilan klinis yang tepat kepada peserta didik (Nielsen et al., 2017). Untu mencapai hasil yang lebih maksimal perlu diterapkan kenyamanan lingkungan tempat pembelajaran berlangsung dan memberikan pengalaman langsung kepada mahasiswa (Heenam, Pharm et al., 2017). Preceptor juga dapat menerapkan pembelajaran sebaya guna menciptakan ruang bagi mahasiswa untuk bertanggungjawab atas pembelajaran mereka sendiri, menggali pengetahuan dan mendorong mahasiswa berpikir kritis. Hasil penelitian menunjukkan bahwa preceptor memahami bahwa pembelajaran sebaya memungkinkan mahasiswa untuk mengambil langkah mundur yang memberi mereka peran dan perspektif baru. Tujuannya adalah para mahasiswa dapat lebih mandiri (Nygren, Carlson, 2017). 


\section{SIMPULAN}

Penelitian ini menghasilkan modul asuhan persalinan kala III sebagai bahan ajar mahasiswa DIII Kebidanan dalam mata kuliah ASKEB II (Persalinan). Hasil pengukuran dan evaluasi dalam penelitian ini menunjukan modul asuhan persalinan kala III dengan metode preceptorship lebih baik meningkatkan keterampilan asuhan bayi baru lahir, manajemen aktif kala III dan pemantauan perdarahan dibandingkan kelompok modul dan demonstrasi serta demonstrasi saja.

\section{SARAN}

Modul dapat dijadikan sebagai media pembelajaran yang sangat dibutuhkan oleh mahasiswa sebagai bahan pembelajaran mandiri yang dibuat berdasarkan kebutuhan mahasiswa dan bertujuan untuk mempermudah mahasiswa mencapai tujuan pembelajaran.

Penelitian selanjutnya, diperlukan pengembangan pembuatan modul berupa emodul yang mudah diakses kapanpun dan dimanapun oleh mahasiswa, pembuatan emodul juga mengurangi penggunaan kertas untuk mencetak modul sebelum dibagikan pada mahasiswa, e-modul dapat mencegah mahasiswa modul mahasiswa tersebut hilang atau rusak.

\section{DAFTAR PUSTAKA}

Astuti, S. L. D., \& Surasmis, A. (2016). Pengaruh Penyuluhan Kesehatan tentang Menyusui dengan Metode Demonstrasi terhadap Kemampuan Ibu Menyusui di Rumah Bersalin Wilayah Banjarsari Surakarta. Interest: Jurnal Ilmu Kesehatan, 5(2), 116-124

Coates, R., Rocca. I. L., Olander, E., Ayers, S., \& Salmon, D. (2018). A Postgraduate Optimum Birth Module to Increase Midwives' Readiness to Work in MidwiferyLed Settings: A Mixed-Methods Evaluation. Birth, August, 1-7. https://doi.org/10.1111/birt.12399

Davies, L., Page, N., Glover, H., \& Sudbury, H. (2016). Developing a Perinatal Mental Health Module: An Integrated Care Approach. British Journal of Midwifery, 24(2), 118-121. https://doi.org/10.12968/bjom.2016.24.2.118

Fazelniya, Z., Najafi, M., Moafi, A., \& Talakoub, S. (2018). The Impact of an Interactive Computer Game on the Quality of Life of Children Undergoing Chemotherapy Background: Materials and Methods: Results: Conclusions. Iranian Journal of Nursing and Midwifery Research, 22(6), 431-435. https://doi.org/10.4103/ijnmr.IJNMR

Heenam, D., Pharm. D., M., Kyungwoo, B. P., Lee, S. P. ., Jinyong, B. P., \& Hyeno, P. (2017). Stress, Satisfaction, Incentives, and Competency of Hospital Pharmacy Preceptors Joining the Newly Implemented Six-Year Pharmacy Program in South Korea. Clinical Research Laboratory College of Pharmacy

Higgins, A., Carroll, M., \& Sharek, D. (2016). Impact of Perinatal Mental Health Education on Student Midwives' Knowledge, Skills and Attitudes: A Pre/Post Evaluation of a Module of Study. Nurse Education Today, 36, 364-369. https://doi.org/10.1016/j.nedt.2015.09.007

Lestari, K. P., Siswanto, J., Sriningsih, I., \& Setyowati, S. E. (2019). Pelatihan Instruktur Klinik: Metode Perseptor dalam Pembelajaran Klinik di Lingkungan Dinas Kesehatan Kota Semarang. Link, 15(1), 7. https://doi.org/10.31983/link.v15i1.3923 
Nielsen, K., Finderup, J., Brahe, L., Elgaard, R., Elsborg, A. M., Engell-Soerensen, V., Holm, L., Juul, H., \& Sommer, I. (2017). The Art of Preceptorship. A Qualitative Study. Nurse Education in Practice, 26, 39-45. https://doi.org/10.1016/j.nepr.2017.06.009

Nurmala, C. (2018). Pengaruh Penerapan Model Pembelajaran Asuhan Nifas Terintegrasi Terhadap Peningkatan Kompetensi Mahasiswa D-III Kebidanan. JKAKJ, 2(1), 21-29

Nygren, F., \& Carlson, E. (2017). Preceptors Conceptions of a Peer Learning Model: A Phenomenographic Study. Nurse Education Today, 49, 12-16. https://doi.org/10.1016/j.nedt.2016.10.015

Rahmadhayanti, E., \& Kamtini, D. I. (2018). Pengaruh Pemberian Rangsangan Puting Susu terhadap Lama Kala III pada Ibu Bersalin. 9, 188-197

Ruwihapsari, Z., \& Maryana. (2018). The Influence of Health Educationusing Menarche Module Towards. 7(1), 17-24

Setyorini, R. H. (2017). Proses Pembelajaran Manajemen Aktif Kala III Mahasiswa Diploma III Kebidanan. Jurnal Ilmiah Bidan, 2(2), 45-50

Stefely, J. A., Theisen, E., Hanewall, C., Scholl, L., Burkard, M. E., Huttenlocher, A., \& Yu, J. P. J. (2019). A Physician-Scientist Preceptorship in Clinical and Translational Research Enhances Training and Mentorship. BMC Medical Education, 19(1), 1-11. https://doi.org/10.1186/s12909-019-1523-0

Susanti, A. I., Wirakusumah, F., \& Garna, H. (2016). Metode Pembelajaran Preceptorship Dibandingkan dengan Konvensional terhadap Keterampilan Pemeriksaan Kehamilan Mahasiswi Kebidanan. Jurnal Sistem Kesehatan, 2(1), 34-39. https://doi.org/10.24198/jsk.v2i1.10417

Utami, N. W. (2018). Pencapaian Kompetensi Asuhan Keperawatan dengan Menggunakan Modul Praktikum. 7(1), 20-24

Vasconcelos, F. B., Katz, L., Coutinho, I., Lins, V. L., \& de Amorim, M. M. (2018). Placental Cord Drainage in the Third Stage of Labor: Randomized Clinical Trial. PLoS ONE, 13(5), 1-10. https://doi.org/10.1371/journal.pone.0195650

Vihos, J., Myrick, F., \& Yonge, O. (2019). Socializing for Authentic Caring Engagement in Nursing Practice: Nursing Student Moral Development in Preceptorship. The Canadian Journal of Nursing Research = Revue Canadienne de Recherche En Sciences Infirmieres, 51(2), 63-71. https://doi.org/10.1177/0844562118809258 